\title{
Index System Establishment of "Guidelines for the Construction of Park City" Referring to International Experience
}

\author{
Chen Yan ${ }^{1, \mathrm{a}}$, Cai Wenting ${ }^{1, \mathrm{~b}}$, Wang $\mathrm{Yu}^{1, \mathrm{c}}$, Wang Xiangchun ${ }^{1, \mathrm{~d}^{*}}$, and Jiang $\mathrm{Na}^{1, \mathrm{e}}$ \\ ${ }^{1}$ China Urban Construction Design \& Research Institute Co., Ltd. (CUCD), Beijing, China
}

\begin{abstract}
As a new mode of urban planning and construction under the guidance of socialism with Chinese characteristics in the new era, park city construction provides a new direction for green, high-quality and sustainable development of Chinese cities. In order to achieve the vision of park city, Hubei Province of China issued China's first local standard, "Guidelines for the Construction of Park City", in 2019, putting forward the indicators and relevant requirements for the construction of park city which covering urban planning, construction and governance. In this paper, the index system of Sustainable Development of United Nations, British National Park City of London, master plan of New York and Resilient Chicago, "Garden City" of Singapore concerning urban planning and construction has been reviewed during preparation, which lay a good foundation for the establishment of "Guidelines for the Construction of Park City". The guidelines show the thoughts and basic contents of the index system establishment, and clarify specific construction requirements from 7 aspects including ecological environment, living environment, safety environment, cityscape, industrial development and social governance, which provide a profound basis and reference for the construction and development of China's Park City.
\end{abstract}

\section{Introduction}

In the process of urban development, with the accleleration of urbanization and the improvement of economic level, a large number of urban problems have emerged, such as ecological deterioration, environmental pollution, and insufficient supply of ecological products, which hinder the high-quality and sustainable development of the city to some extent. Therefore, people begin to explore how to improve urban living environment from diverse perspectives like ecology, function, and society. The concepts of "garden city", "ecological city" and "green city" provide ideas and methods for modern urban planning and construction. Since 1990, a series of urban construction and development models, such as "health city", "scenic city", "landscape city" and "ecological landscape city", have been proposed in China to deal with the problems of urban development in different stages and under specific background of times. In 2018, General Secretary $\mathrm{Xi}$ put forward the construction of "Park City" as a new mode of urban development in the new era of ecological civilization construction, which reflects the higher requirements of the central government for the original urban development mode and further efforts on exploring green and sustainable development. Many experts and scholars as well as local cities have taken the lead in the research on Park City construction, including the backgrounds, connotations, characteristics, construction path and indicators of Park City. In 2019, Hubei Province issued the

\footnotetext{
* Corresponding author: wangxiangchun@cucd.cn
}

achenyanshengtai@cucd.cn, ${ }^{b}$ caiwenting@cucd.cn, ${ }^{c}$ wangyu@cucd.cn, ${ }^{\mathrm{a}}$ jiangna@cucd.cn first local standard, "Guidelines for the Construction of Park City", which setting out indicators and relevant requirements for Park City ranging from urban planning, construction to governance. The author of this paper, as the main completer of this guidelines, studied and drew on the advanced experience of urban planning and construction in developed countries involving ecological environment protection and construction,urban sustainable development an so on in the process of compiling the standard. The summary and analysis are as follows, which could provide the basis and reference for the green and sustainable development of cities and achieve the vision of Park City.

\section{Index system of international urban planning and construction}

\subsection{Index system of Sustainable Development of United Nations}

The United Nations Commission on Sustainable Development (CSD) was established in December, 1992 with the approval of the United Nations General Assembly, aiming to ensure the effective implementation of the follow-up actions by the United Nations Conference on Environment and Development (UNCED) (namely, the Earth Summit). In 2007, the UNCED issued the third edition of "Indicators of Sustainable Development: Guidelines and Methodologies"[1]. The proposed sustainable development index system contains a set of 96 
indicators, among which there are 50 core indicators, covering three aspects of society, environment and economy. Social indicators reflect urban living standards, such as the proportion of people with income below the national poverty line, the proportion of people with access to improved drinking water sources, and the percentage of people with access to basic medical facilities. Environmental indicators reflect the situation of ecological environment, such as the proportion of natural ecological reserves, carbon dioxide emissions, etc. Economic indicators reflect the degree and efficiency of economic development, such as per capita GDP, material utilization intensity, etc.

In September 2015, the countries of the world approved the "2030 Agenda for Sustainable Development" ${ }^{\text {"[2] }}$ and its 17 sustainable development goals, which established over the achievements of the Millennium Development Goals and aimded to further

Table 1. UN sustainable development goals and indicators 1. eradicate poverty in all its forms. The unique feature of new goals is that it calls on all countries, regardless of poor, rich and middle-income countries, to act together to promote prosperity and protect the planet. The sustainable development goals recognize that efforts to eradicate poverty need to be accompanied by strategies that promote economic growth, meet social needs such as education, health, social protection and employment opportunities, and address climate change and environmental protection. Based on the 17 sustainable development goals of the United Nations, the United Nations Commission on sustainable development released a new version of global indicator framework, in which each target section sets a detailed breakdown of goals and corresponding indicators, reaching a total of 232 indicators. The indicators related to park city construction are summarized as shown in Table

6.1.1 Proportion of population safely managed drinking water services

6.3.1 Proportion of waste water safely treated

6.3.2 Proportion of bodies of water with good ambient water quality

6.4.2 Level of water stress: freshwater withdrawal as a proportion of available freshwater resources

6.b.1 Proportion of local administrative units with established and operational policies and procedures for participation of local communities in water and sanitation management

Goal 7. Ensure access to affordable, 7.1.1 Proportion of population with access to electricity

reliable, sustainable and modern energy for all

7.1.2 Proportion of population with primary reliance on clean fuels and technology 7.2.1 Proportion of population with primary reliance on clean fuels and technology

11.2.1 Proportion of population that has convenient access to public transport, by sex, age and persons with disabilities

11.3.1 Ratio of land consumption rate to population growth rate

11.3.2 Proportion of cities with a direct participation structure of civil society in urban planning and management that operate regularly and democratically

Goal 11. Make cities and human settlements inclusive, safe, resilient and sustainable

11.6.1 Proportion of urban solid waste regularly collected and with adequate final discharge out of total urban solid waste generated, by cities

11.6.2 Annual mean levels of fine particulate matter (e.g. PM2.5 and PM10) in cities (population weighted)

11.7.1 Average share of the built-up area of cities that is open space for public use for all, by sex, age and persons with disabilities

12.4.1 Number of parties to international multilateral environmental agreements on hazardous waste, and other chemicals that meet their commitments and obligations in transmitting information as required by each relevant agreement

Goal 12. Ensure sustainable consumption $\quad$ 12.4.2 Hazardous waste generated per capita and proportion of hazardous waste treated, by type and production patterns

of treatment

12.5.1 National recycling rate, tons of material recycled

12.c.1 Amount of fossil-fuel subsidies per unit of GDP (production and consumption) and as a proportion of total national expenditure on fossil fuels

15.1.1 Forest area as a proportion of total land area

15.1.2 Proportion of important sites for terrestrial and freshwater biodiversity that are covered by protected areas, by ecosystem type

15.2.1 Progress towards sustainable forest management

15.3.1 Proportion of land that is degraded over total land area

15.4.1 Coverage by protected areas of important sites for mountain biodiversity

15.4.2 Mountain Green Cover Index

15.5.1 Red List Index

\subsection{The goal of National Park City in London}

In 2018, Sadig Khan, the mayor of London, announced his ambitious plan to turn the British capital into the world's first "National Park City" and strengthen planning methods to achieve the goal of making London the greenest city in the world. Table 2 shows the understanding of the mayor and the city's partners on the National Park City, that is, the goals and strategic plans to achieve the construction of a National Park City. 
Table 2. The goals and path of London National Park

\begin{tabular}{|l|l|}
\hline Goal & Implemention strategy \\
\hline $\begin{array}{l}\text { Protect and increase green spaces in the } \\
\text { capital }\end{array}$ & $\begin{array}{l}\text { Develope a 'challenge map' highlighting areas where green infrastructures } \\
\text { should be prioritied as a part of the mayor's target to make London } \\
\text { achieve a green coverage rate over 50\% }\end{array}$ \\
\hline $\begin{array}{l}\text { Improve the accessibility of green spaces } \\
\text { for Londoners of all ages, particularly those } \\
\text { areas that are currently lacking in greenery }\end{array}$ & $\begin{array}{l}\text { Establish a Green Space Council to work with environmental experts to help } \\
\text { boroughs attract investment for transforming and protecting their parks and } \\
\text { green Spaces. }\end{array}$ \\
\hline $\begin{array}{l}\text { Enhance the quality of green space, and } \\
\text { ensure they are well maintained to create } \\
\text { healthy habitats for wildlife }\end{array}$ & $\begin{array}{l}\text { Developing new "urban greening elements" to ensure green roofs, green walls } \\
- \text { growing plants and grass along busy roads -- helps reduce pollution, with } \\
\text { trees and rain gardens being incorporated into new developments in } \\
\text { London.The mayor will also use his planning authority to protect our green } \\
\text { belts and urban open land }\end{array}$ \\
\hline $\begin{array}{l}\text { Value the health, environmental, social and } \\
\text { economic benefits and values that London's } \\
\text { green Spaces bring to the capital }\end{array}$ & $\begin{array}{l}\text { Focus on improving green coverage for "gray" space. With more Londoners } \\
\text { living in flats, working in high-rise offices and fewer people having access to } \\
\text { private gardens, the mayor wants to ensure that more streets and public } \\
\text { spaces become greener to improve health and encourage more walking and } \\
\text { cycling activities }\end{array}$ \\
\hline
\end{tabular}

On the basis of setting National Park City requirements, the planning methods used by the mayor to achieve the above goals include strengthening the government's protection of the green belt, green space and natural environment through planning approval, while adding more green roofs, green walls, rain gardens and wildlife habitats in the new projects, and investing more on community green spaces and parks to plant a large number of new trees. The mayor would launch the first 9 million pounds of "Greener City Fund", which can be applied by community groups for new trees and maintenance in the community. It took the mayor just three years to invest in planting 170,000 trees and implement 200 green space improvement projects, which covering more than 175 hectares. The mayor's professional team pioneered the high-tech London green coverage map to identify the scope of London's greenery and help monitor these improvement projects which were in line with the mayor's goal.

\subsection{Indicators of urban planning in the United States}

\subsubsection{Indicators of New York City Master Plan}

Throughout the history of New York City, it has experienced six urban planning from the first regional planning in 1921 to the fourth comprehensive planning "PlaNYC2030: A Greener, Greater New York" in 2007 and "One New York: The Plan for A Strong and Just City (One NYC)" released in April 2015, which can be regarded as classic cases of urban planning and construction,

driving New York to stay ahead of the times.

In 2015, New York released the fifth edition of urban planning 'One NYC', which was committed to New York City's economic growth, sustainability and resilience, but also to addressing equity issues and providing a strategic plan to achieve this goal together. "One NYC" developed strategies to address income inequality and the impact of climate change, while building a platform for economic growth and vitality in the next century. The plan set out four visions for implementing the plan, namely: our growing prosperous city, our fair and just city, a sustainable city and a resilient city. The vision for sustainability means that "New York will become the most sustainable city in the world, leading the world in dealing with climate change". This vision included minimizing New York's environmental footprint, reducing greenhouse gas emissions, and having the cleanest air and water in any city in the United States. The highlight of the equity vision was to build an inclusive economy that provides highpaying jobs. The sustainability and resilience component also integrates the city's vision of equity. For climate adaptation, the plan described efforts to reduce flooding in Southeast Queens and develop a workforce development program to ensure resilience goals and create labours. The plan also worked to strengthen community-based organizations, improve emergency shelters and cooling centres in low-income and vulnerable communities, and increase the resilience of public housing. It can be seen that this plan embodies the idea of people-oriented and taking people's own interests as the goal ${ }^{[3]}$. In order to achieve the goal of One NYC, a set of key index system is developed with data being released every year. This set of index system includes 55 quantitative indicators. Some relevant indicators are extracted as shown in Table 3.

Table 3. Selected indicators of one NYC.

\begin{tabular}{|l|l|l|c|c|}
\hline Vison & Goal & Indicator & Target & $\begin{array}{l}\text { Figure for most } \\
\text { recent year }\end{array}$ \\
\hline \multirow{2}{*}{$\begin{array}{l}\text { Vision 1 } \\
\text { : Our } \begin{array}{l}\text { Growing,thriving } \\
\text { city }\end{array}\end{array}$} & Vision-level Indicators & Total number of jobs & $\begin{array}{l}4.896 \text { million by } \\
2040\end{array}$ & 4.166 million \\
\cline { 2 - 5 } & $\begin{array}{l}\text { Number of jobs accessible to } \\
\text { the average New Yorker } \\
\text { within 45 minutes by transit }\end{array}$ & 1.8 million by 2040 & 1.4 million \\
\cline { 2 - 5 } & $\begin{array}{l}\text { Housing Supply } \\
\text { \& Affordability }\end{array}$ & $\begin{array}{l}\text { Number of new construction } \\
\text { affordable housing units }\end{array}$ & 80,000 by 2024 & 6,191 units \\
\cline { 2 - 5 } & $\begin{array}{l}\text { Number of affordable housing } \\
\text { units preserved }\end{array}$ & 120,000 by 2024 & 11,185 units \\
\hline
\end{tabular}




\begin{tabular}{|c|c|c|c|c|}
\hline & Culture & $\begin{array}{l}\text { Number of public cultural and } \\
\text { civic events in community } \\
\text { districts with the highest rates } \\
\text { of poverty and lowest rates } \\
\text { of public cultural and civic } \\
\text { programming }\end{array}$ & Increase & N/A \\
\hline & \multirow[t]{2}{*}{ Transportation } & $\begin{array}{l}\text { Overall rail transit capacity into } \\
\text { the Manhattan core } \\
\text { measure ( } 8 \mathrm{am}-9 \mathrm{am})\end{array}$ & $\begin{array}{l}20 \% \text { Increase } \\
(2040)\end{array}$ & $627,890(2015)$ \\
\hline & & $\begin{array}{l}\text { NYC In-Season Commuter } \\
\text { Cycling Index }\end{array}$ & $844(2020)$ & 437 \\
\hline & \multirow{2}{*}{ Broadband } & $\begin{array}{l}\text { Number of NYers with } \\
\text { (affordable, reliable, high- } \\
\text { speed) } \\
\text { internet service at home }\end{array}$ & $100 \%$ by（2050） & $78.10 \%$ \\
\hline & & $\begin{array}{l}\% \text { of New Yorkers with access } \\
\text { to free public WiFi within } \\
1 / 8 \text { th of a mile from home }\end{array}$ & $\begin{array}{l}\text { Cover a crucial } \\
\text { mass of } \\
\text { public spaces }\end{array}$ & $13.90 \%$ \\
\hline \multirow{4}{*}{$\begin{array}{l}\text { Vision 2: Our just } \\
\text { and equitable city }\end{array}$} & Vision-level indicator & $\begin{array}{l}\text { Poverty Rate: Number of New } \\
\text { Yorkers in or near poverty }\end{array}$ & $\begin{array}{l}800,000 \text { people } \\
\text { lifted out of poverty } \\
\text { or near poverty by } \\
2025\end{array}$ & 3.7 million \\
\hline & \multirow{2}{*}{$\begin{array}{l}\text { Healthy neighborhoods, } \\
\text { active living }\end{array}$} & $\begin{array}{l}\text { Percentage of adult New } \\
\text { Yorkers that meet physical } \\
\text { activity recommendations }\end{array}$ & $80 \%(2035)$ & $67 \%$ \\
\hline & & $\begin{array}{l}\text { Average number of servings of } \\
\text { fruits and vegetables that } \\
\text { adult New Yorkers eat per day }\end{array}$ & $\begin{array}{l}3 \text { mean servings } \\
(25 \% \text { increase }) \\
\text { by } 2035 \\
\end{array}$ & 2.4 mean servings \\
\hline & Access to healthcare & $\begin{array}{l}\text { Percentage of New Yorkers that } \\
\text { felt that they received the } \\
\text { medical care that they have } \\
\text { needed in the past } 12 \text { months }\end{array}$ & Increase & $89 \%$ \\
\hline \multirow{9}{*}{$\begin{array}{l}\text { Vision 3: Our } \\
\text { sustainable city } \\
\text { continued }\end{array}$} & \multirow{3}{*}{ Vision-level indicator } & $\begin{array}{l}\text { Greenhouse gas emissions } \\
\text { reductions relative to } 2005\end{array}$ & $\begin{array}{l}80 \% \text { reduction by } \\
2050 \text { relative } \\
\text { to } 2005\end{array}$ & $19 \%$ \\
\hline & & $\begin{array}{l}\text { Reduction in total waste } \\
\text { disposed relative to } 2005\end{array}$ & $\begin{array}{l}90 \% \text { reduction by } \\
2030 \\
\end{array}$ & $12 \%$ \\
\hline & & $\begin{array}{l}\text { Reduce risk of stormwater } \\
\text { flooding in most affected } \\
\text { communites }\end{array}$ & Decrease & \\
\hline & Zero Waste & zero waste to landfills by 2030 & -- & -- \\
\hline & Air quality & $\begin{array}{l}\text { Disparity in PM2.5 levels } \\
\text { across city neighborhoods }\end{array}$ & $\begin{array}{l}20 \% \text { reduction }(5.32 \\
\mathrm{mg} / \mathrm{m} 3) \text { by } \\
2030\end{array}$ & $\begin{array}{c}6.65 \mathrm{mg} / \mathrm{m} 3 \text { range } \\
\text { annual average } \\
\text { across } \\
\text { CDs } 2013\end{array}$ \\
\hline & Brownfields & $\begin{array}{l}\text { Number of tax lots remediated } \\
\text { since January } 1,2014\end{array}$ & $750(\mathrm{Q} 1,2019)$ & 71 \\
\hline & \multirow{2}{*}{ Water management } & $\begin{array}{l}\text { Violations with Safe Drinking } \\
\text { Water Act }\end{array}$ & $\begin{array}{l}\text { No SDWA } \\
\text { violations }\end{array}$ & $\begin{array}{l}0 \text { violations of } \\
\text { SDWA }\end{array}$ \\
\hline & & $\begin{array}{l}\text { Combined Sewer Overflow } \\
\text { capture rate }\end{array}$ & Increasing & $78 \%$ \\
\hline & $\begin{array}{l}\text { Parks and natural } \\
\text { resources }\end{array}$ & $\begin{array}{l}\text { Percentage of New Yorkers } \\
\text { living within a walking } \\
\text { distance of a park }\end{array}$ & $85 \%$ by 2030 & $79.50 \%$ \\
\hline \multirow{6}{*}{$\begin{array}{l}\text { Vision 4: Our } \\
\text { Resilient City }\end{array}$} & \multirow{2}{*}{ Vision-level indicators } & $\begin{array}{l}\text { Reduce the Social Vulnerability } \\
\text { Index for neighborhoods across } \\
\text { the city }\end{array}$ & Reduce & 4 \\
\hline & & $\begin{array}{l}\text { Reduce average annual } \\
\text { economic losses resulting from } \\
\text { climate related events }\end{array}$ & Reduce & \$1.7B \\
\hline & \multirow{2}{*}{ Neighborhoods } & $\begin{array}{l}\text { Capacity of accessible } \\
\text { emergency shelters }\end{array}$ & 120000 & 10000 \\
\hline & & $\begin{array}{l}\text { Rate of volunteerism among } \\
\text { New Yorkers }\end{array}$ & $25 \%$ by 2020 & $18 \%$ \\
\hline & \multirow[b]{2}{*}{ Infrastructure } & $\begin{array}{l}\text { Customer-hours of weather- } \\
\text { related utility and transit } \\
\text { space service outages }\end{array}$ & Decrease & $55 \%$ \\
\hline & & $\begin{array}{l}\text { Percentage of hospital and long- } \\
\text { term care beds } \\
\text { benefitting from facility } \\
\text { retrofits for resiliency }\end{array}$ & $100 \%$ by 2020 & - \\
\hline
\end{tabular}




\subsubsection{Indicators of Chicago's Resilient City}

Chicago's strategic development has identified four resilience challenges, namely narrowing the gap between Chicago communities, addressing the root causes of crime and violence, ensuring the provision of critical infrastructure, and promoting participatory, preparedness and solidarity of communities. Chicago's resilient city is committed to addressing these challenges by creating a more connected city where residents, communities, institutions, companies and government agencies are successfully tied together. Chicago's resilient city is organized by three pillars including strong neighborhoods, robust infrastructure and prepared communities involving 12 goals and 50 actions set for support. The strategic framework is shown in Table 4.

Table 4. Strategic Framework for Chicago's Resilient City

\begin{tabular}{|c|c|c|}
\hline \multirow[t]{7}{*}{ Vision } & \multirow[t]{7}{*}{ Connected Chicago } & Residents Connected to Opportunity \\
\hline & & Neighbors Connected to Each Other \\
\hline & & Communities Connected to Other Communities \\
\hline & & Government Connected to Residents \\
\hline & & City Government Connected \& Collaborating \\
\hline & & Regional Governments Connected \& Working Together \\
\hline & & Healthy Communities Connected to Nature \\
\hline \multirow[t]{4}{*}{ Pillar 1} & \multirow[t]{4}{*}{ Strong Neighborhoods } & $\begin{array}{l}\text { Coordinate city investments and actions to maximize and empower neighborhood } \\
\text { development }\end{array}$ \\
\hline & & $\begin{array}{l}\text { Increase jobs and investment leveraged through community action in communities } \\
\text { with historic underinvestment. }\end{array}$ \\
\hline & & $\begin{array}{l}\text { Create a process to renew and build community trust and social cohesion between } \\
\text { city government and residents. }\end{array}$ \\
\hline & & Ensure the protection and enhancement of basic needs for Chicagoans \\
\hline \multirow[t]{4}{*}{ Pillar 2} & \multirow[t]{4}{*}{ Robust Infrastructure } & $\begin{array}{l}\text { Improve infrastructure planning to ensure that investments are more strategic, } \\
\text { proactive, and coordinated. }\end{array}$ \\
\hline & & $\begin{array}{l}\text { Increase investment in green infrastructure to reduce flood risk and create more } \\
\text { sustainable neighborhoods. }\end{array}$ \\
\hline & & $\begin{array}{l}\text { Improve transportation connections between areas with high unemployment and } \\
\text { workforce opportunities. }\end{array}$ \\
\hline & & $\begin{array}{l}\text { Reduce citywide greenhouse gas emissions (GHG) through city renewable energy } \\
\text { generation, energy efficiency, and mobility options. }\end{array}$ \\
\hline \multirow[t]{4}{*}{ Pillar 3} & \multirow[t]{4}{*}{ Prepared Communities } & Improve communication tools to create informed and engaged Chicagoans. \\
\hline & & Reduce vulnerabilities to extreme weather events for disconnected Chicagoans. \\
\hline & & $\begin{array}{l}\text { Increase social connectedness and personal resilience of City first responders to } \\
\text { better serve residents. }\end{array}$ \\
\hline & & Leverage technology to increase accessibility and impact of information. \\
\hline
\end{tabular}

\subsection{Singapore's Strategies of "City in Garden" and "City in Nature"}

Singapore regards the construction of a "Garden City" as a basic national policy. After half a century of unremitting efforts, focusing on greening and comprehensive environmental improvement, Singapore has finally transformed from a poor, messy island country into a beautiful and eye-catching "Garden City" ${ }^{[4]}$. In this process, we can systematically learn the experience of Singapore from the top-level design to the implementation of planning and construction, which is of great inspiration to China's construction of Park City.

(1) Raising urban environmental improvement to the level of national strategy, while strengthening the toplevel design. Singapore is the first country taking the construction of "garden city" as its basic national policy. In the early days of the founding of the Republic of Singapore, it introduced the important strategy of "garden city" in the face of significant ecological and living environment problems and ensured that environmental remediation and ecological greening construction remain as long-term basic national policy ${ }^{[5,6]}$.

(2) Developing a scientific and efficient, ecologically diverse, harmonious and open urban "blue-green" integrated system. The core part of Singapore's construction experience is aimed at the establishment of detailed implementation rules ${ }^{[5]}$. The most important step is to quickly improve green coverage by planting trees in residential areas, commercial areas, industrial areas and government construction sites, and promote the implementation of three-dimensional greening, including wall greening, roof greening, fence greening, bridge greening and other greening forms, so as to create a vibrant appearance of city ${ }^{[7]}$. In the index system of Park City construction, these measures mentioned above can be reflected as "greening rate of built-up area", "ratio of three-dimensional greening" and "proportion of garden type residentials". In the general blueprint of Singapore, the target of providing 0.8 hectares of green space per 1000 people is set, which can be reflected in the index system of Park City as "area of park and green space per capita" and "area of residential green space per capita". Singapore's government attaches great importance to the cultivation of new varieties and the domestication of exotic plants on the basis of protecting the existing ancient and famous trees ${ }^{[8]}$.

At present, Singapore has put forward a new concept of transforming the existing "garden city" into "City in Garden" and "City in Nature", that is, a city where people live, work and play in garden. To better achieve this goal, 
Singapore has developed the "Singapore Green Plan 2030", a national sustainable development agenda including an action plan concerning all dimensions of life. The key strategic concerns of "City in Garden" and "City in Nature" include park blueprint, park connector network, master blueprint of parks and water bodies, streetscape master blueprint, skyrise greenery, public participation in greening projects, sustainable living, green economy and resilient future ${ }^{[8]}$, as shown in Table 5 .

Table 5. Key strategies of Singapore's "City in nature".

\begin{tabular}{|c|c|}
\hline $\begin{array}{l}\text { Important } \\
\text { strategy }\end{array}$ & Concern \\
\hline Park Blueprint & $\begin{array}{l}\text { Connect parks and nature reserves as far as } \\
\text { possible to form an integrated green space } \\
\text { network }\end{array}$ \\
\hline $\begin{array}{l}\text { Park Connector } \\
\text { Network }\end{array}$ & $\begin{array}{l}\text { Connect existing natural, cultural, historical } \\
\text { and recreational sites and linking } \\
\text { communities together to ensure all } \\
\text { households within a } 10 \text {-minute walk from a } \\
\text { park }\end{array}$ \\
\hline $\begin{array}{l}\text { Master blueprint } \\
\text { for parks and } \\
\text { water bodies }\end{array}$ & $\begin{array}{l}\text { Open the catchment area and the northern } \\
\text { wetland, and build a pro-level platform on the } \\
\text { green corridor }\end{array}$ \\
\hline $\begin{array}{l}\text { Streetscape master } \\
\text { blueprint }\end{array}$ & $\begin{array}{l}\text { Park trunk roads in urban areas, forest roads } \\
\text { in forest areas, coastal roads in coastline, } \\
\text { rural roads in suburbs, and welcome roads at } \\
\text { main entrances and exits }\end{array}$ \\
\hline Skyrise Greenery & $\begin{array}{l}\text { vertical greening, roof greening, balcony } \\
\text { courtyard construction }\end{array}$ \\
\hline $\begin{array}{l}\text { Public } \\
\text { participation in } \\
\text { greening projects }\end{array}$ & $\begin{array}{l}\text { Park adoption programs, park watch } \\
\text { programs, community gardening programs }\end{array}$ \\
\hline Sustainable Living & $\begin{array}{l}\text { Reduce waste sent to our landfill per capita } \\
\text { per day by } 20 \% \text { by } 2026 \text {, with the goal of } \\
\text { reaching } 30 \% \text { by } 2030 \text {, At least } 20 \% \text { of } \\
\text { schools to be carbon neutral by } 2030\end{array}$ \\
\hline Green Economy & $\begin{array}{l}\text { Be a leading centre for Green Finance in Asia } \\
\text { and globally, }\end{array}$ \\
\hline Resilient Future & $\begin{array}{l}\text { protect our coastlines, moderate rise in urban } \\
\text { heat }\end{array}$ \\
\hline
\end{tabular}

It can be seen that the construction of "City in nature" focuses on the construction of the park system. The adoption of the design technique of integrated blue and green spaces connect reserved lands of around waterways with parks, roads with roads, parks and nature reserve,

Table 6. Key fields and indicators of urban planning and construction. wetlands and so on, which not only increases the greening, but also protects the developed water system.

\section{Establishment of index system of "Guidelines for the Construction of Park City"}

\subsection{International experience for reference}

By summarizing and analyzing the international experience in the establishment of urban planning and construction index system, it can be seen that foreign countries attach great importance to the concept of sustainable development. At the same time, the ecological environment protection, the improvement of the quality of human settlements, the strengthening of infrastructure construction, the protection of urban human history and so on, have become hot spots in the process of urban planning and construction, as well as a future trend.

(1) Ideas that could be refered. Foreign countries attach great importance to the concept of sustainable development. Based on this, they integrate the ideas of "fairness" and "people-oriented" to urban planning, and actively guide the public to participate in urban planning, construction and management.

(2) Areas focused on and indicators for reference. The theory and practice of urban planning and construction have been developing and evolving in the past 100 years, shifting from the initial focus on architectural planning to multi-disciplinary participation in planning research and practice. Based on the analysis of the urban planning and construction index system of the United Kingdom, the United States and Singapore, it is found that the key fields concerning current urban planning and construction mainly include urban environment, housing, transportation, urban infrastructure, urban public facilities, urban culture, etc., that is, strengthening ecological protection, environmental improvement, landscape and cultural protection, and improving urban basic service functions, as shown in Table 6.

\begin{tabular}{|c|c|c|}
\hline Category & Indicators & \\
\hline \multirow{10}{*}{$\begin{array}{l}\text { Ecological environmental } \\
\text { protection }\end{array}$} & \multirow{4}{*}{ Biodiversity } & Biodiversity index \\
\hline & & Land area with high ecological value \\
\hline & & Land nature reserve area \\
\hline & & Area of water nature reserves \\
\hline & \multirow{3}{*}{ Ecological space protection } & Proportion of protected land \\
\hline & & Ecological corridor protection \\
\hline & & Landscape vision protection \\
\hline & \multirow{3}{*}{$\begin{array}{l}\text { Rational utilization and } \\
\text { protection of natural resources }\end{array}$} & The proportion of forest area \\
\hline & & The proportion of fresh water resources already used \\
\hline & & Recommend native plants \\
\hline \multirow{10}{*}{ Urban environment } & \multirow{5}{*}{ Atmosphere } & Annual mean value of fine particulate matter \\
\hline & & Carbon dioxide emissions \\
\hline & & Standard air pollutant composite index \\
\hline & & Percentage of vehicles that use clean energy \\
\hline & & Advocate public transportation \\
\hline & \multirow{2}{*}{ Waste } & Waste disposal rate \\
\hline & & Waste recycling rate \\
\hline & \multirow{2}{*}{ Water } & Sewage treatment rate \\
\hline & & Water quality up to standard \\
\hline & Urban water environment & Ratio of blue and green space \\
\hline
\end{tabular}




\begin{tabular}{|c|c|c|}
\hline & \multirow{5}{*}{ management } & Ratio of natural river bank \\
\hline & & Bank control rate \\
\hline & & Water purification \\
\hline & & Urban water supply and drainage design \\
\hline & & Areas prone to flooding \\
\hline & \multirow{5}{*}{ Community } & Community connectivity \\
\hline & & $\begin{array}{l}\text { Ratio of households can access to a park within a 10-minute } \\
\text { walk }\end{array}$ \\
\hline & & Accessible emergency shelter capacity \\
\hline & & Community supply rate of leisure and recreation facilities \\
\hline & & Number of communities in the garden \\
\hline & \multirow{3}{*}{ Public participation } & Environmental Awareness \\
\hline & & Carry out environmental activities \\
\hline & & Participation of environmental management systems \\
\hline \multirow{6}{*}{ Park system } & \multirow[b]{2}{*}{ Park network } & $\begin{array}{l}\text { Connect parks and nature reserves as far as possible to form an } \\
\text { integrated green space network }\end{array}$ \\
\hline & & $\begin{array}{l}\text { Connect existing natural, cultural, historical and recreational } \\
\text { sites and linking communities togetherto ensure that all } \\
\text { households can access to a park within a } 10 \text {-minute walk }\end{array}$ \\
\hline & Parks and water bodies & Build a pro-level platform on the green corridor \\
\hline & Street landscape & $\begin{array}{l}\text { Park trunk roads in urban areas, forest roads in forest areas, } \\
\text { coastal roads in coastline, rural roads in suburbs, and welcome } \\
\text { roads at main entrances and exits }\end{array}$ \\
\hline & Skyrise greenery & $\begin{array}{l}\text { vertical greening, roof greening, balcony courtyard } \\
\text { construction }\end{array}$ \\
\hline & Public participation & Participate in park management, etc. \\
\hline \multirow{5}{*}{ City landscape } & Building height & $\begin{array}{l}\text { The height of the building conforms to the terrain, and } 20 \% \text { - } \\
30 \% \text { of the mountain view is not blocked by the building }\end{array}$ \\
\hline & \multirow{4}{*}{ Building coordination } & $\begin{array}{l}\text { The degree of harmony between the building and the } \\
\text { surrounding landscape }\end{array}$ \\
\hline & & Preserve and restore historical and cultural buildings \\
\hline & & Preserve and improve local landmarks \\
\hline & & Street landscape construction \\
\hline \multirow[t]{2}{*}{ Urban services } & network & $\begin{array}{l}\text { Number of people access to (affordable, reliable, high-speed) } \\
\text { internet service at home }\end{array}$ \\
\hline & infrastructure & Intelligent transportation, shopping, etc. \\
\hline
\end{tabular}

\subsection{Establishment of index system of "Guidelines for the Construction of Park City"}

\subsubsection{General idea design}

The "Guidelines for the Construction of Park City" emphasizes the importance of planning to lead the Park City construction. It is required that planning and construction should be considered simultaneously, and the overall planning and top-level design should be done well in the direction of needs, problems and results. Park City construction should adhere to the ideas of peopleorientation, and make progress under the guidance of green development, sustainable development and highquality development, and in the same time, it reflects six values including ecology, livelihood, aesthetics, culture, development and society. We should respect the natural and human endowments, build park-like cities with beautiful ecological space, moderate living space, intensive and efficient production space, distinctive, afe and open regional and cultural characteristics. Based on the principles of open and co-governance, scientific and efficient, harmony and stability, this paper provides guidance for the formulation of Park City planning from six aspects including ecological value requirements, aesthetic value requirements, cultural value requirements, development value requirements, and social value requirements. The specific construction requirements are put forward from seven perspective involving ecological environment, park system, living environment, safety environment, cityscape, industrial development, and social governance, while clarified the key direction, important areas and main objectives of Park City construction, which provides decision-making reference for the government to build Park City.

\subsubsection{Establishment of Index System}

The framework structure of the "Guidelines" consists of three levels of Park City planning, construction and governance. Construction section invole seven special objectives including ecological environment, park system, living environment, safety environment, distinctive features, industrial development and social governance, while giving qualitative suggestions and 51 quantitative indicators, respectively. The important indicators extracted in this paper are briefly summarized as shown in Table 7. 
Table 7. Part of the indicators of "Guidelines for the Construction of Park City"

\begin{tabular}{|c|c|c|}
\hline Primary indicator & No. & Secondary indicators \\
\hline \multirow{6}{*}{ Ecological environment } & 1 & The proportion of blue and green space $\geqslant 65 \%$ \\
\hline & 2 & Ecological environmental condition index $\geqslant 75$ \\
\hline & 3 & Intensity of urban heat island effect $\leqslant 2.5^{\circ} \mathrm{C}$ \\
\hline & 4 & Urban forest coverage rate $\geqslant 30 \%$ \\
\hline & 5 & Comprehensive species index $\geqslant 0.6$ \\
\hline & 6 & Black and smelly water treatment rate to $100 \%$ \\
\hline \multirow{4}{*}{ Park system } & 1 & Urban park green area per capita $\geqslant 15 \mathrm{~m}^{2}$ \\
\hline & 2 & The lowest park green area per capita in each urban area $\geqslant 5.5 \mathrm{~m}^{2}$ \\
\hline & 3 & $\begin{array}{l}\text { Landscape recreation green space area per capita within the urban development } \\
\text { boundary } \geqslant 10 \mathrm{~m}^{2}\end{array}$ \\
\hline & 4 & Coverage of urban park green space within $500 \mathrm{~m}$ service radius $\geqslant 90 \%$ \\
\hline \multirow{10}{*}{ Living environment } & 1 & Urban greening coverage rate $\geqslant 40 \%$ \\
\hline & 2 & Urban green land rate $\geqslant 35 \%$ \\
\hline & 3 & Avenue covered by tree promotion rate $\geqslant 85 \%$ \\
\hline & 4 & Community shared green space area per capita $\geqslant 1.5 \mathrm{~m}^{2}$ \\
\hline & 5 & The number of days with good air quality in a year $\geqslant 292$ days \\
\hline & 6 & Gym area per capita $\geqslant 2$ square meters \\
\hline & 7 & Public water supply penetration rate $\geqslant 90 \%$ \\
\hline & 8 & Sewage treatment rate $\geqslant 90 \%$ \\
\hline & 9 & Household waste recycling rate $\geqslant 35 \%$ \\
\hline & 10 & Public transport sharing rate $\geqslant 60 \%$ \\
\hline \multirow{5}{*}{ Safe environment } & 1 & Standard highway traffic safety facilities $\geqslant 80 \%$ \\
\hline & 2 & $\begin{array}{l}\text { The coverage of emergency shelters in urban communities within a service radius of } \\
500 \text { meters will be } 100 \%\end{array}$ \\
\hline & 3 & The proportion of green buildings in new buildings $\geqslant 70 \%$ \\
\hline & 4 & New energy vehicles and achieve VI emission standard ratio $\geqslant 80 \%$ \\
\hline & 5 & The parking lot charging pile allocation rate $\geqslant 80 \%$ \\
\hline Characteristic features & 1 & Appearing assesment value of city $\geqslant 9.00$ \\
\hline Industrial development & 1 & The contribution rate of green industries to GDP growth $\geqslant 50 \%$ \\
\hline \multirow{3}{*}{ Social governance } & 1 & Residents' participation in renovation of old residential areas $\geqslant 90 \%$ \\
\hline & 2 & Implementation rate of theme activities in the comprehensive park $\geqslant 1$ times/month \\
\hline & 3 & Free opening rate of park green space should reach $100 \%$ \\
\hline
\end{tabular}

\section{Conclusions}

This paper mainly showed the previous analysis and thoughts on how to establish index system and indicators of China's Park City construction. As we know, the concept of "Park City" proposed in China is a new vision on developmemt, and at the preliminary stage of Park City construction, top design and targets setting are crucial to better promotion of Park City. In view of this, the establishment of index system and preperation of guidelines could take the lead in better understanding of park city construction and instructing practitioner of urban planning, construction and governance related to work professionally, especially for the administrators of local cities, clear indicators help them understand the difference between the target and the reality, as well as the important projects where should be paid attention.

According to comprehensive review on the index system or indicators of urban planning and construction, as well as the establishment of index system for China's Park City construction, it is not difficult to find that the construction of green home is the common dream of people across the world. In the new era of ecological civilization construction, Park City construction is an important method to solve the contradictions brought by industrial civilization, promote the harmonious coexistence of "human and nature" and the sustainable development of the city, and achieve the symbiotic development of "human, city and park". Generally speaking, it is believed by the author that the Park City construction has the following development trends:

(1) Adhere to ecology as a priority, and strive to create a city with a high degree of integration of landscape and ecology and a harmonious symbiosis between city and nature. The construction of Park City should develop towards the two-way development of the "high-value" landscape and the "high-quality" ecology, taking nature as the beauty, protecting the nature, and reaching the beautiful urban park form and spatial pattern.

(2) Adhere to the people-oriented idea to create a livable and comfortable living environment. Under the bottom line thinking of reverence for nature, the development of cities should pay more attention to the needs of "people", especially giving full consideration to the reasonable satisfaction of the individual needs of all kinds of people, and creating a park city with sound infrastructure, perfect public services that everyone can enjoy in order to meet people's living needs, ensure people's safety and enhance resilience of cities. Meanwhile, people should be guided to participate in urban planning, construction and governance, from a 
simple multi-subject co-governance to a more cohesive social governance community.

(3) Pay attention to protect and perform the ecological value of "mountain, water, forest, farmland, lake and grasses". It is significant for the construction and development of Park City to practice the theory that "blue water and green mountains are wealth", activate the vitality of the city, and maximize ecological value and functional benefit within the scope of urban available space.

\section{Acknowledgments}

This paper is one of the stage achievements of the National Key Research and Development Program of China, "Research on the characteristic index system of rural ecological landscape resources" (2019YFD1100401) and the academy-level project of China Urban Construction Research Institute Co., Ltd, "Study on the Evaluation Technique of Regional Ecosystem Gross Product (GEP) "(YQ23Y21023).

\section{References}

1. United Nations. Indicators of Sustainable Development: Guidelines and Methodologies. (2007)

2. United Nations. Sustainable Development Goals.https://www.un.org/sustainabledevelopment/z $\mathrm{h} /$ development-agenda/.(2015)

3. Z. Zhao. Urban Insight..52.112-118(2017)

4. X.S. Xie. Southeast Asia and South Asian Studies. 5255(2009)

5. J. Wang, H. Liu. Urban Insight. 5-16(2015)

6. J. L. Chen. Central China Normal University. The Experience of Singapores of Econogical Environment Construction :From "Environmental Authoritarianism" to "Environmental Democracy". (2018)

7. Y. Z. Yi. CHJS. 45-47(2015)

8. F. X. Cai. CSLA. 27-29(2008) 